\title{
EDUCATION FOR SUSTAINABLE DEVELOPMENT: NEW OPPORTUNITIES WITH THE RCE NETWORK
}

\author{
M.V. Yurina ${ }^{1}$, Y.V. Lopukhova ${ }^{2}$, G.D. Kuznetsova ${ }^{3}$ \\ ${ }^{1,2}$ Samara State Technical University \\ 244, Molodogvardeyskaya str., Samara, 443100, Russian Federation \\ ${ }^{3}$ Moscow State University of Geodesy and Cartography \\ 4, Gorokhovsky per., Moscow, 105064, Russian Federation \\ ${ }^{1}$ E-mail:urri_2000@mail.ru \\ ${ }^{2}$ E-mail: j.v.lopukhova@mail.ru \\ ${ }^{3}$ E-mail: gd-kuznetsova@yandex.ru
}

\begin{abstract}
The goals of sustainable development can not be achieved only through technological innovation, policy decisions and financial support. Education for sustainable development (ESD) makes it possible to deal constructively and creatively with current and future global challenges and to create a sustainable society. A special place in the global distribution of ESD is currently played by the network of Regional centres of expertise (RCE) established under the auspices of the UN University. The RSEs form a global network of formal and non-formal educational institutions and organizations to mobilize them in the field of ESD. Currently, this network includes more than 168 centers, two of which are located in Russia. According to the profiles of RCEs worldwide the main objective of their activities is consolidation of educational efforts of universities and different cultural and environmental institutions and organizations, together with the municipality, for increasing public awareness of sustainable development. The key partners of RCEs, the leading regional Universities, combined on one platform, are acting as an educational consortium, which is mainstreaming ESD by its appropriate integration in the curricula of formal education, from early childhood rearing to primary, secondary, technical and vocational and higher education, and also nonformal education initiatives, particularly through sustainabilityrelated intended learning outcomes. The article summarizes the experience of RCEs in the field of ESD, highlights the most promising activities, forms of implementation of RCE projects together with universities, identifies the most urgent needs of educational institutions in the field of ESD. The authors of this article found themselves in a situation where after the merger of two regional universities the RCE previously hosted by one of them (RCE Samara, Russia) requires brand new start. Obviously there was a lack of a formal conceptual framework for development in the previous period. Thus, the article is an attempt to find new ideas and new ways of development for the existing center, to make it a leading

${ }^{1}$ Mariya V. Yurina, Cand. Ped. Sci., Associate Professor of Linguistics, Intercultural Communication and Russian as a Foreign Language Department

${ }^{2}$ Yuliya V. Lopukhova, Doc. Ped. Sci., Head of Linguistics, Intercultural Communication and Russian as a Foreign Language Department

${ }^{3}$ Galina D. Kuznetsova, Cand. Biol. Sci., Associare Professor of Space Monitoring and Ecology Department
\end{abstract}


example in Russia of the power of education for sustainable development, where people of all ages are given the knowledge and tools they need to assume responsibility for creating a better tomorrow and a sustainable future.

Keywords: curriculum, education for sustainable development, educational consortium, higher education, sustainable development.

\section{Introduction}

More and more countries recognize education for sustainable development (ESD) as an integral part of quality education and a key factor for sustainable development itself. In Russia, there are still problems both in the implementation and in the understanding of the phenomenon. The term "Sustainable Development" was introduced 30 years ago in the report of the UN International Commission on environment and development "Our common future". It was officially recognized internationally in 1992. The main document adopted at that time - "Agenda 21" points to the importance of reorienting education systems to promote sustainable development and raise awareness of the problems of the world. However, the modern understanding of ESD was formed later, and it includes three components - environmental, social and economic - equally. The modern definition from UNESCO is as follows: "Education for sustainable development empowers people to change the way they think and work towards a sustainable future" [Education for Sustainable Development, 2019]. UNESCO aims to improve access to quality education on sustainable development and help people develop knowledge, skills, values and behaviours needed for sustainable development. It is about including sustainable development issues, such as climate change and biodiversity into teaching and learning. Individuals are encouraged to be responsible actors who resolve challenges, respect cultural diversity and contribute to creating a more sustainable world.

ESD has been also defined in the UN Sustainable Development Goals: "Obtaining a quality education is the foundation to creating sustainable development. In addition to improving quality of life, access to inclusive education can help equip locals with the tools required to develop innovative solutions to the world's greatest problems" [Sustainable Development Goals, 2017].

So far, Russia is lagging behind the international community on the development and implementation of ESD, which is evident in the low involvement of Russian organizations and initiatives in the international dialogue on these issues. In 2017, Russia issued presidential instructions to the government "on the inclusion in the Federal state educational standards of requirements for the development of basic knowledge in the field of environmental protection and sustainable development" [National Goals and Strategic Objectives of the Russian Federation, 2018]. Moreover, education for sustainable development should not be limited to the level of universities. Especially important is the training of those who have already received a diploma and now holds key positions [Vaschekin, 2001]. Government of- 
ficials often use the term "Sustainable Development" without fully understanding what is behind it. That is why it is necessary to create an educational system that can both teach ESD skills and inform about the latest trends in this area.

An important role in promoting ESD in many countries is played by Regional centres of expertise (RCE) established under the auspices of the UN University and forming a global network of formal and non-formal educational institutions and organizations to mobilize them in the field of ESD [Mochizuki, 2008; Tare, 2018]. Initially, RCEs were conceived as intermediaries between local authorities and educational organizations. The RCE network brings together multi-sectoral and interdisciplinary members who might not usually work together: formal education institutions, informal educators, local authorities. According to RCE Mission, "RCEs help prepare local leaders of tomorrow with the tools and information they need to make smart and sustainable choices for the future. RCE efforts encourage innovation and new approaches to sustainable development. They translate existing knowledge into concrete actions and empower individuals to make sustainable choices for themselves and their communities" [RCE Vision and Mission, 2018[. Their five priority areas of action are: "advancing policy by mainstreaming ESD, transforming learning and training environments using the whole-institution approach, building capacities of educators and trainers, empowering and mobilizing youth, and finally accelerating sustainable solutions at the local level" [RCE Vision and Mission, 2018]. At all levels of society, RCEs play a crucial role in implementing these goals using their local knowledge and global network. Local knowledge, expertise, and best practices are shared globally through the network and can be adapted and applied successfully in other regions. RCEs also play a central role in the transfer of global technologies, knowledge, and experiences at the local level through their programmes and activities.

\section{Methodology}

A brief description of RCE Samara, which was approved in 2007, is followed by the description of the contribution of Samara State Technical University to the RCE's starting phase and in the near future after the merger of two regional universities. The initiative of restarting the RCE Samara as well as the design and implementation of the ESD programme developed through the collaboration of institutes and research centers:Volga Resource Center for Environmental Engineering and Chemical Technology, Scientific-Analytical Center for Industrial Ecology, Research and Education Center on Environmental Monitoring, Forecasting and Reducing the Impact of Technical Systems on the Biosphere,the Institute of Social and Human Sciences and Technologies, the Institute of Architecture and Civil Engineering. The programme will focus on students carrying out participatory action research enabled by collaboration with regional stakeholders on ESD and SD. 


\section{Results}

The RCE Samara was acknowledged in August, 2007, and was the first center in Russia and one of the first centers in Europe along with the centers in Munich, Graz and Skane. The key partner and the hosting organization of RCE Samara is Samara State Technical University. After the merger of two regional universities (Samara State Technical University and Samara State University of Architecture and Civil Engineering) the RCE previously hosted by one of them (SGASU) requires brand new start.

\section{Characteristics of the region}

Samara is one of the largest cities in Russia, located in the south-east of European Russia on the Volga River. Population is more than a million people. Just across the river there is Samarskaya Luka National Park with the Zhiguli Mountains and Nature Preserve. Samara has a rich history of more than 400 years and architectural heritage of Russian wooden architecture. Samara Region faces several social and environmental challenges, such as preservation of cultural and architectural heritage, social adaptation of migrants, supporting ethnic diversity, air, water, and land pollution, deforestation.

\section{Vision of the RCE}

With the above characteristics and history as its background, the RCE Samara has the following vision.

- It will create a platform of dialogue among various ESD stakeholders in the region and promote collaboration with the initiative of the institutions of higher education. We expect that it will enhance the social capital of the regional community, which will be the foundation for sustainable development.

- While including environmental education as an important issue, we will emphasize the development and promotion of programmes to incorporate ESD with a wider scope of formal and non-formal education including higher education. Through this, we aim at enhancing people's awareness and activities on SD and ESD in the regional community.

- The concept of ESD and its realisation can have significant impact on education and learning [Sterling, 2008; Van der Branden, 2012; Hoffmann, Siege, 2008; Deepshikha, 2018]. RCE Samara will strive to contribute to the transformation of education and learning through ESD.

\section{Samara State Technical University and its initiative in the RCE}

Samara State Technical University (SSTU) today is the largest technopolis of the Volga region, which in 2014 celebrated its 100th anniversary. The whole era of the formation and development of engineering education and science of the Samara region and neighboring regions is connected precisely with our university. SSTU 
today is a major scientific and educational center in the region, where specialists are trained for the energy, oil and gas, chemical and petrochemical, engineering, transport, food, defense industries, information technology, instrument engineering, automation and control in technical systems, materials science and metallurgy, biotechnology, industrial ecology. Today SSTU is a basic platform for constructive interaction of a scientific school and industry. The close connection of the academic community with production, the solution of specific practical problems that practitioners put before scientists and teachers of the university, allowed to create a special environment. It is the integration of science, technology and engineering education. This makes it possible for a university to receive a clear understanding of the requirements for key competencies of a graduate from employers and quickly adjust educational programs, and the synthesis of technical, humanitarian and economic fields of knowledge in one university allows scientists to successfully apply fundamental knowledge to solve practical applied problems not only of industrial enterprises in the region. We believe that SSTU has the potential to contribute to further expanding the scope of ESD practices.

SSTU has numerous research centers. The most important of them are: Volga Resource Center for Environmental Engineering and Chemical Technology, Scientific-Analytical Center for Industrial Ecology, Research and Education Center on Environmental Monitoring, Forecasting and Reducing the Impact of Technical Systems on the Biosphere. But SSTU's research and action cover areas beyond environmental education. As mentioned above, SSTU now includes the Institute of Architecture and Civil Engineering (ex-SGASU) which works on technologies to restore products of cultural and historical heritage and engineering use with the application of casting technologies, additive technologies and reverse engineering; on urban planning regulation of architectural and historical environment etc. An important role is played by the Institute of Social and Human Sciences and Technologies. The students are trained for effective communication in English, they are introduced to the nuances of socio-cultural and ethnic sensitivities. English is the language of communication between RCEs and ESD stakeholders internationally. This is a hurdle for Russian regional stakeholders. Human resources at the University will be able to support them in clearing the hurdle and in developing the international network. It will enable ESD stakeholders to share information on good practices on ESD, promote international mutual understanding, and raise awareness of global problems for sustainability.

\section{Development of an ESD programme at Samara State technical University}

In relation to ESD there is a wide consensus that education of this manner should not merely be confined to formal education institutions [Degtyareva, 2016; Ilyn, 2017]. Instead it should transcend barriers and be incorporated into the lifelong learning of individuals and thus society as a whole. Approaching ESD learn- 
ing in this way allows an individual to expand on what they have learnt at various stages, following a knowledge connection process [Mochizuki \& Fadeeva, 2008; Kasimov et al, 2005; Souza, 2016; Filho et al, 2017].

SSTU is developing a new ESD programme with its focus on action research, in which students participate in practices and activities in various fields of ESD and SD. The programme aims at increasing the capacity of students in leading and promoting ESD in various fields of society, and certificates of "ESD practitioner" will be granted to those who fulfil certain requirements. It will be a collaborative project of three departments: Research and Education Center on Environmental Monitoring, Forecasting and Reducing the Impact of Technical Systems on the Biosphere, the Institute of Social and Human Sciences and Technologies, the Institute of Architecture and Civil Engineering. These institutes started to develop a unique curriculum as an optional sub-course that involves sharing educational resources including subjects concerning ESD and research fields. This course will help students to be aware of the world in which they live and to gain an understanding of the interactions between multifaceted economic, social and environmental problems, including the contribution of individuals to these processes. This is the moment, when the collaboration of the University and RCE can be mutually beneficial in terms of outcomes for both partners. The task of RCE is to facilitate the collaboration between pre-existing local and regional stakeholders, creating a global learning space [Mochizuki \& Fadeeva, 2008; Sterling, 2001; Leicht et al, 2018; Barth et al, 2015]. Establishing connections between authorities, employers and HEIs is a stimulus for implementing ESD into the whole Samara region. The RCE Samara as it was started from a university base has the potential to provide knowledge hubs, as well as to link learning with action.

The ESD programme at the university is valuable not only because it helps develop ESD practitioners and leaders, but also because with the help of RCE it activates the ESD activities in the community. The collaboration between citizen groups and university students and staff will strengthen the partnership and is expected to lead to empowerment of citizens in the regional community. It will provide feedback for the development of the RCE and for raising awareness of ESD in the region.

\section{The prospects of development of RCE Samara}

Although the main focus of interest among staff members who are working on the ESD programme and the RCE Samara has been higher education, adult education, and informal learning in civil society, supporting ESD activities in primary and secondary education in the region is also an important mission of the RCE. In Russia, the importance of environmental education and trans-disciplinary integrated learning has been widely recognized, and various efforts and good practices have been studied. The tentative plan for the RCE Samara is to conduct a survey of 
the status of ESD in higher education as well as in primary and secondary schools, collect information on good practices in the region, and open a forum to exchange information between teachers and other stakeholders in the region.

The contribution of institutes of higher education should not come from just one institute. Other universities in the region will be invited to join the RCE network and activities. We will also promote participation of a wide range of departments within the SSTU in the ESD programme and RCE activities.

\section{Conclusions}

In this paper, we introduced the RCE Samara established in 2007 and the contribution of SSTU in the RCE's restarting phase. Activities and projects related to ESD that existed earlier at the university played an important role in the initiative, formation of the network, and directing the RCE activities. SSTU is preparing to start a new ESD programme for undergraduate students with a focus on participatory action research, which is enabled by collaboration with regional stakeholders on ESD including RCE members.

\section{REFERENCES}

1. UNESCO, Education for Sustainable Development, 2019. https://en.unesco.org/themes/education-sustainable-development

2. United Nations Sustainable Development Goals, 2017. https://www.un.org/ sustainabledevelopment/education/

3. National Goals and Strategic Objectives of the Russian Federation, 2018. Official Internet Resources of the President of Russia. http://kremlin.ru/events/ president $/$ news $/ 57425$

4. Vashekin N., Delokarov K., Ursul A. Obrazovaniye i ustoychivoye razvitiye. Kontseptual'nyye problemy [Education and Sustainable Development. Conceptual problems]. M.: MGUK, 2001.320 p.

5. Mochizuki Y. The RCE Initiative as a Policy Instrument for Sustainable Development: Can it Match the World Heritage List and the Global Compact? Journal of Education for Sustainable Development. 2008, Volume 2. Pp. 61-71.

6. Tare M. Advancing Education for Sustainable Development Goals through Regional Centers of Expertise (RCE), 2018. https:/www.triplepundit.com/story/2018/ advancing-education-sustainable-development-goals-through-regional-centers-expertiserce/11546

7. RCE Vision and Mission. Global RCE Network, 2018. http://www.rcenetwork.org/ portal/rce-vision-and-mission

8. Sterling $S$. Sustainable education - towards a deep learning response to unsustainability, 2008. https://www.developmenteducationreview.com/issue/issue-6/sustainableeducation-towards-deep-learning-response-unsustainability 
9. Van der Branden K. Sustainable education: basic principles and strategic recommendations. School Effectiveness and School Improvement. An International Journal of Research, Policy and Practice, 2012, Vol. 23. Pp. 285-304.

10. Hoffmann T., Siege H. What is Education for Sustainable Development? 2008. http://www.esd-expert.net/files/ESD-Expert/pdf/Was_wir_tun/Lehr$\% 20 u n d \% 20$ Lernmaterialien/What_is_Education_for_Sustainable_Development.pdf

11. Deepshikha D. Education for sustainable development: A conceptual model of sustainable education for India, 2018. https://www.researchgate.net/ publication/329309588_Education_for_sustainable_development_A_conceptual_model_of_s ustainable_education_for_India

12. Degtyareva I.V., Shalina O.I., Tokareva G.F. Transformatsiya universitetskogo obrazovaniya $\mathrm{v}$ kontekste ustoychivogo razvitiya [Transformation of higher education in the context of sustainable development]. Sovremennoye obrazovaniye [Contemporary education], 2016, № 2. Pp. 1-11.

13. Ilyn I.V., Ursul A.D., Ursul T.A. [et al.]. Obrazovaniye dlya ustoychivogo razvitiya v Rossii: problemy i perspektivy (ekspertno-analiticheskiy doklad) [Education for sustainable development in Russia: problems and prospects (Expert-analytical report)]. M.: Publishing house of Moscow University, 2017.

14. Mochizuki Y., Fadeeva Z. Regional Centres of Expertise on Education for Sustainable Development (RCEs): an overview. International Journal of Sustainability in Higher Education, 2008, Vol. 9, No. 4. Pp. 369-381. https://doi.org/ $10.1108 / 14676370810905490$

15. Kasimov N.S., Malkhazova S.M., Romanova E.P. Environmental Education for Sustainable Development in Russia. Journal of Geography in Higher Education, 2005, Vol. 29, No. 1. Pp. 51-61.

16. Souza P. Paving the way for sustainable education design, 2016. https://www.usgbc.org/articles/paving-way-sustainable-education-design

17. Filho W.L., Azeiteiro U.M., Alves F. [et al.]. Handbook of Theory and Practice of Sustainable Development in Higher Education. Springer International Publishing, 2017. 540 p.

18. Sterling S. Sustainable Education: Revisioning Learning and Change. UIT Cambridge Ltd., 2001, 96 p.

19. Leicht A., Heiss J., Byun W.J. Issues and Trends in Education for Sustainable Development. UNESCO Publishing, 2018. 278 p.

20. Barth M., Michelsen G., Rieckmann M. [et al.]. Handbook of Higher Education for Sustainable Development. Routledge, 2015. 480 p.

Original article submitted 25.10.2019

Revision submitted 29.11.2019 


\title{
УДК 378 \\ ОБРАЗОВАНИЕ В ИНТЕРЕСАХ УСТОЙЧИВОГО РАЗВИТИЯ: НОВЫЕ ВОЗМОЖНОСТИ В РАМКАХ СЕТИ РЕГИОНАЛЬНЫХ ЦЕНТРОВ ЭКСПЕРТИЗЫ
}

\author{
М.В. Юрина ${ }^{1}$, Ю.В. Лопухова ${ }^{2}$, Г.Д. Кузнецова ${ }^{3}$ \\ ${ }^{1,2}$ Самарский государственный технический университет \\ Российская Федерация, 443100, г. Самара, ул. Молодогвардейская, 244 \\ ${ }^{3}$ Московский государственный университет геодезии и картографии \\ Российская Федерачия, 105064, г. Москва, Гороховский переулок, 4 \\ ${ }^{1}$ E-mail:urri_2000@mail.ru \\ ${ }^{2}$ E-mail:j.v.lopukhova@mail.ru \\ ${ }^{3}$ E-mail: gd-kuznetsova@yandex.ru
}

\section{Аннотация}

Цели устойчивого развития не могут быть достигнуты только за счет технологических инновачий, политических решений и финансовой поддержки. Образование в интересах устойчивого развития (ОУР) позволяет конструктивно и творчески решать текущие и будущче глобальные проблемы и создавать устойчивое общество. Особое место в глобальном распространении ОУР в настоящее время занимает сеть региональных иентров экспертизы (РЦЭ), созданная под эгидой университета ООН. РЦЭ связывают в глобальную сеть множество формальньх и неформальных учебных заведений и организаций, объединяя их идеей образования в интересах устойчивого развития. В настоящее время эта сеть включает в себя более 168 ичентров, два из которых расположены в России. Основной целью деятельности РЦЭ является консолидаџия образовательных усилий университетов и различных культурных и экологических учреждений и организаџий совместно с мунищипалитетами для повышения осведомленности общественности об устойчивом развитии. Ключевые партнеры РЦЭ, ведущуие региональные университеты, объединенные на одной платформе, действуют в качестве образовательного консоричума, задачей которого является интеграция ОУР в учебные программы формального образования начиная с раннего детства и заканчивая начальным, средним техническим и профессиональным и выстим образованием, а также неформальными образовательными инициативами, в частности через связанные с устойчивым развитием результаты обучения. В статье обобщен опыт РЦЭ в области ОУР, вылелены наиболее перспективные направления деятельности, формы реализации проектов РЦЭ совместно с вузами, выявлены наиболее актуальные потребности образовательных учреждений в области ОУР. Авторы данной статьи оказались в ситуации, когда после слияния двух региональных вузов организованный ранее одним из них

${ }^{1}$ Юрина Мария Валерьевна, кандидат филологических наук, доцент кафедры «Лингвистика, межкультурная коммуникация и русский как иностранный»

2 Лопухова Юлия Викторовна, доктор педагогических наук, заведующий кафедрой «Лингвистика, межкультурная коммуникация и русский как иностранный»

${ }^{3}$ Кузнецова Галина Дмитриевна, кандидат биологических наук, доцент кафедры «Космический мониторинг и экология» 
РЦЭ (Самара, Россия) требует новых идей для развития. Очевидно, что в предыдущий период отсутствовала четкая конщептуальная основа деятельности центра. Таким образом, статья представляет собой попытку найти новые идеи и новые пути развития для существующего центра, сделать его ведущим в России примером построения образования для устойчивого развития, где люди всех возрастов получают знания, необходимые им для создания лучшего устойчивого будущего.

Ключевые слова: учебный план, образование для устойчивого развития, образовательный консорииум, высшее образование, устойчивое развитие.

\section{БИБЛИОГРАФИЧЕСКИЙ СПИСОК}

1. UNESCO, Education for Sustainable Development, 2019. https://en.unesco.org/themes/education-sustainable-development

2. United Nations Sustainable Development Goals, 2017. https://www.un.org/ sustainabledevelopment/education/

3. National Goals and Strategic Objectives of the Russian Federation, 2018. Official Internet Resources of the President of Russia. http://kremlin.ru/events/ president $/$ news $/ 57425$

4. Ващекин Н.П., Делокаров К.Х., Урсул А.Д. Образование и устойчивое развитие. Концептуальные проблемы. - М.: МГУК, 2001. - 320 с.

5. Mochizuki Y. The RCE Initiative as a Policy Instrument for Sustainable Development: Can it Match the World Heritage List and the Global Compact? Journal of Education for Sustainable Development. 2008, Vol. 2. Pp. 61-71.

6. Tare M. Advancing Education for Sustainable Development Goals through Regional Centers of Expertise (RCE), 2018. https://www.triplepundit.com/story/ 2018/advancing-education-sustainable-development-goals-through-regional-centersexpertise-rce/11546

7. RCE Vision and Mission. Global RCE Network, 2018. http://www.rcenetwork.org/ portal/rce-vision-and-mission

8. Sterling $S$. Sustainable education - towards a deep learning response to unsustainability, 2008. https://www.developmenteducationreview.com/issue/issue-6/sustainableeducation-towards-deep-learning-response-unsustainability

9. Van der Branden K. Sustainable education: basic principles and strategic recommendations. School Effectiveness and School Improvement. An International Journal of Research, Policy and Practice, 2012, Vol. 23. Pp. 285-304.

10. Hoffmann T., Siege H. What is Education for Sustainable Development? 2008. http://www.esd-expert.net/files/ESD-Expert/pdf/Was_wir_tun/Lehr\%20und\%20Lernmaterialien/What_is_Education_for_Sustainable_Development.pdf

11. Deepshikha D. Education for sustainable development: A conceptual model of sustainable education for India, 2018. https://www.researchgate.net/publication/ 329309588_Education_for_sustainable_development_A_conceptual_model_of_sustai nable_education_for_India 
12. Дегтярева И.В., Шалина О.И., Токарева Г.Ф. Трансформация университетского образования в контексте устойчивого развития // Современное образование. 2016. - № 2. - C. 1-11.

13. Ильин И.В., Урсул А.Д., Урсул Т.А. [и др.]. Образование для устойчивого развития в России: проблемы и перспективы (экспертно-аналитический доклад). - М.: Изд-во Моск. ун-та, 2017.

14. Mochizuki Y., Fadeeva Z. Regional Centres of Expertise on Education for Sustainable Development (RCEs): an overview. International Journal of Sustainability in Higher Education, 2008, Vol. 9, No. 4. Pp. 369-381. https://doi.org/10.1108/ 14676370810905490

15. Kasimov N.S., Malkhazova S.M., Romanova E.P. Environmental Education for Sustainable Development in Russia. Journal of Geography in Higher Education, 2005, Vol. 29, No 1. Pp. 51-61.

16. Souza P. Paving the way for sustainable education design, 2016. https://www.usgbc.org/articles/paving-way-sustainable-education-design

17. Filho W.L., Azeiteiro U.M., Alves F. [et al.]. Handbook of Theory and Practice of Sustainable Development in Higher Education. Springer International Publishing, 2017. $540 \mathrm{p}$.

18. Sterling $S$. Sustainable Education: Revisioning Learning and Change. UIT Cambridge Ltd., 2001, 96 p.

19. Leicht A., Heiss J., Byun W.J. Issues and Trends in Education for Sustainable Development. UNESCO Publishing, 2018. 278 p.

20. Barth M., Michelsen G., Rieckmann M. [et al.]. Handbook of Higher Education for Sustainable Development. Routledge, 2015. 480 p.

Поступила в редакцию 25.10.2019

В окончательном варианте 29.11.2019 